\title{
Pengembangan Metode Griess Dengan Reduktor Logam Seng Berlapis Tembaga Untuk Penetapan Kadar Metabolit Oksida Nitrat Dalam Serum
}

\author{
Sari PMNA ${ }^{1,2}$, Warditiani NK ${ }^{1}$, Astuti NMW ${ }^{\mathbf{1}}$, Wirasuta IMAG ${ }^{1,2}$ \\ ${ }^{1}$ Program Studi Farmasi, Fakultas Matematika dan Ilmu Pengetahuan Alam Universitas \\ Udayana, Badung, Bali, Indonesia 80361 \\ ${ }^{2}$ UPT. Laboratorium Forensik Sains dan Kriminologi Universitas Udayana, Badung, Bali \\ E-mail:nova.armita@unud.ac.id \\ Riwayat artikel: Dikirim: 22/10/2020; Diterima: 18/11/2020, Diterbitkan: 1/07/2021
}

\begin{abstract}
The recent research concerned in method development for determination of nitric oxide metabolites in serum using spectrophotometry visible based on Griess reaction. The reduction of nitrate to nitrite was performed using copper coated zinc. The method was optimized and validated. The determination of total nitrite in samples was started with deproteinization using $\mathrm{ZnSO} 4$ and $\mathrm{NaOH}$. The supernatants were reducted using copper coated zinc, reacted with diazotization and coupling reagents, then incubated. The absorbance was measured using spectrophotometer visible. The optimum reductant mass of copper coated zinc is $1.5 \mathrm{~g}$ with reduction time 10 minutes, coefficient variation $\leq 5 \%$. Linierity of analytical method gives a coefficient correlation, $r>0.995$. Relative procedural standard deviation was $\leq 5 \%$, precision $\leq 15 \%$, and recovery $85-115 \%$.
\end{abstract}

Keywords: Griess, nitric oxide, nitrate, nitrite, reductor, serum

\begin{abstract}
ABSTRAK
Telah dilakukan pengembangan metode dan penetapan kadar metabolit oksida nitrat dalam serum dengan metode spektrofotometri sinar tampak. Pengembangan metode pengukuran kadar total nitrit dalam serum dilakukan dengan reaksi Griess yang diawali dengan reduksi nitrat menjadi nitrit dengan reduktor seng lapis tembaga. Metode dioptimasi dan divalidasi. Pengujian sampel diawali dengan deproteinisasi serum menggunakan $\mathrm{ZnSO}_{4}$ dan $\mathrm{NaOH}$, kemudian supernatan direduksi dengan granul seng lapis tembaga,direaksikan dengan reagen pendiazo dan pengkopling, absorbansinya diukur dengan menggunakan spektrofotometer sinar tampak. Data yang dihasilkan diolah secara statitistik. Massa reduktor granul seng lapis tembaga yang optimal adalah 1,5 g dengan waktu reduksi 10 menit, koefisien variansi $\leq 5 \%$. Koefisien korelasi $>0,995$ dengan $\mathrm{Vx} 0 \leq 5 \%$, keseksamaan $\leq 15 \%$, dan kecermatan $85-115 \%$.
\end{abstract}

Kata Kunci: Griess, nitrat, nitrit, oksida nitrat, reduktor, serum

\section{PENDAHUluaN}

Nitric Oxide atau Oksida Nitrat (NO) merupakan signaling molecule yang bersifat permeabel terhadap membran sel yang terlibat dalam berbagai proses biologi melalui kemampuannya dalam memodifikasi protein, lemak dan DNA serta mempengaruhi fungsi dan imunogenesitasnya (Oates, 2010). NO bertindak sebagai intermediet reaktif yang dapat menginduksi autoimunitas selular dan berkontribusi dalam respon imun bawaan yang berkepanjangan, serta dalam kerusakan organ pada penderita Systemic Lupus Erithematosus /SLE. Sementara itu, beberapa studi pada pasien reumatoid artritis (RA) 
DOI : https://doi.org/10.24843/JFU.2021.v10.i01.p09

pISSN: 2301-7716; eISSN: 2622-4607

Jurnal Farmasi Udayana, Vol 10, No 1, Tahun 2021, 79 - 85

didokumentasikan mengalami kenaikan sintesis NO endogen yang mengindikasikan bahwa produksi berlebih NO memiliki peranan yang penting dalam patogenesis RA. Peradangan sendi pada RA merupakan sumber NO yang paling mendominasi. Sel T pada pasien RA akan menghasilkan NO 2,5 kali lebih banyak dibandingkan dengan orang normal (Nagy et al, 2010).

Silver (2011) menyatakan bahwa pada kondisi peradangan kronis cenderung terlihat kadar NO yang tinggi, seperti halnya pada keadaan terjadinya sepsis. Tahap awal terjadinya sepsis dikenal sebagai sindrom respons inflamasi sistemik (SIRS). SIRS menunjukkan berbagai macam gejala, yang mana banyak di antaranya tidak bersifat spesifik, sehingga SIRS sulit untuk didiagnosis. Deteksi dini sepsis dapat meningkatkan outcome pasien dengan mengarahkan pemberian terapi antibiotik atau terapi resusitasi cairan.

Sementara itu pada pasien dengan Penyakit Paru Obstruktif Kronis (PPOK), tingkat fractional exhaled nitric oxide (FeNO) dapat berhubungan dengan kebiasaan merokok dan tingkat keparahan penyakit, yang juga berbanding lurus dengan dengan berbagai parameter fungsional sistem pernapasan. FeNO juga meningkat pada pasien dengan eksaserbasi PPOK. Pengukuran FeNO mungkin berguna dalam pengaturan klinis untuk mengidentifikasi tingkat peradangan saluran napas, dan dalam kaitannya dengan penyakit penyerta, seperti hipertensi arteri paru dan penyakit kardiovaskular (Malerba et al, 2014). Dengan demikian dapat dikatakan bahwa NO memiliki peranan yang sangat penting dalam berbagai patogenitas penyakit dan dapat digunakan dalam memprediksi progresifitas dan status suatu penyakit.

Metabolit NO yang jumlahnya paling banyak dan paling stabil adalah nitrit dan nitrat, oleh karena itu paling sering dianalisis secara kuantitatif (Tatsch et al, 2010). Nitrit dan nitrat digunakan sebagai indeks dari produksi NO secara menyeluruh. Metode yang paling sering dan paling umum digunakan dalam penetapan nitrit adalah dengan reaksi Griess, bahkan sudah banyak kit yang beredar di pasaran yang didasarkan pada reaksi Griess hanya saja harganya relatif mahal dan reduktor yang digunakan masih memiliki keterbatasan, antara lain kestabilan, biaya, massa dan waktu reduksi yang lama.

\section{BAHAN DAN METODE Bahan dan Alat}

Bahan-bahan yang digunakan dalam penelitian ini meliputi granul cadmium $(\mathrm{Cd})$ (Analar), granul seng ( $\mathrm{Zn}$ ) (Analar), $\mathrm{H}_{2} \mathrm{SO}_{4}$ (Merck), glisin (Sigma), $\mathrm{NaOH}$ (Merck), sulfanilamid (Merck), $\mathrm{HCl}$ (Merck), nnaftiletilendiamin (NED) dihidroklorida (Fluka), standar $\mathrm{NaNO}_{2}$ (Merck), $\mathrm{ZnSO}_{4}$ (Merck), $\mathrm{CuSO}_{4}$ (Merck) dan air bebas ion.

Alat yang digunakan dalam penelitian meliputi alat-alat gelas yang umum digunakan dalam laboratorium kimia klinik, neraca analitik (Mettler Toledo), alat sentrifugasi (Sigma 203), lemari es, pH meter (Mettler Toledo), shaker (Super Mixer), tabung vakutainer dan instrumen spektrofotometer UV-Visible (Hitachi U 2900).

\section{Metode}

\section{Penyiapan Granul Kadmium dan Seng}

Granul kadmium dan seng dipotong menjadi serpihan yang lebih kecil. Disimpan dalam larutan $\mathrm{H}_{2} \mathrm{SO}_{4}$ 0,1 M. Granul ini stabil untuk disimpan selama 9 bulan.

\section{Penyiapan Dapar Glisin pH 9,7}

Sebanyak $0,75 \mathrm{~g}$ glisin dalam labu ukur $50 \mathrm{~mL}$ dilarutkakn dengan sedikit air, lalu digenapkan sampai dengan $50 \mathrm{~mL}$ kemudian 
diatur pH-nya dengan larutan $\mathrm{NaOH} 2 \mathrm{M}$. Dibuat segar.

\section{Penyiapan Pereaksi Diazotasi}

Pereaksi diazotasi adalah larutan sulfanilamid dalam $\mathrm{HCl} 3 \mathrm{M}$. Sebanyak $0,5 \mathrm{~g}$ sulfanilamid dalam labu ukur $50 \mathrm{~mL}$ dilarutkan dengan sedikit $\mathrm{HCl} 3 \mathrm{M}$ hangat, lalu digenapkan sampai dengan $50 \mathrm{~mL}$. Disimpan pada suhu $0^{\circ}-8^{\circ}$ Penyiapan Pereaksi Kopling

Sebanyak $10 \mathrm{mg}$ n-naftiletilendiamin dalam labu ukur $50 \mathrm{~mL}$ dilarutkan dengan sedikit air, lalu digenapkan sampai dengan $50 \mathrm{~mL}$. Disimpan pada suhu $0^{\circ}-8^{\circ} \mathrm{C}$.

\section{Aktivasi Granul Kadmium dan Seng}

Sebanyak 0,5-1,5 g granul dicuci tiga kali menggunakan air. Kocok granul selama 2 menit dalam larutan $\mathrm{CuSO}_{4} 5 \mathrm{mM}$ dalam dapar glisin. Keringkan, kemudian cuci granul tiga kali dengan dapar glisin. Setelah digunakan, granul dicuci dan disimpan dalam larutan $\mathrm{H}_{2} \mathrm{SO}_{4} \quad 0,1 \quad$ M. Granul dapat digunakan lagi dengan mengulang prosedur deposit dengan $\mathrm{CuSO}_{4}$.

\section{Optimasi Massa dan Waktu Inkubasi Reduksi Nitrat}

Sebanyak $250 \mu \mathrm{L}$ larutan simulasi air bebas ion dengan konsentrasi nitrit $50 \mu \mathrm{M}$ dipipet ke dalam tabung reaksi, ditambahkan $1 \mathrm{~mL}$ air bebas ion. Kemudian 0,5 mL larutan dipindahkan ke tabung reaksi lainnya. Kemudian ditambahkan reduktor berupa granul $\mathrm{Zn}$ atau granul $\mathrm{Cd}$ yang sudah diaktivasi. Massa reduktor $\mathrm{Zn}-\mathrm{Cu} / \mathrm{Cd}-\mathrm{Cu}$ divariasikan dari 0,5-1,5 gram. Sampel direduksi dengan $\mathrm{Zn}-\mathrm{Cu}$ selama 10 menit dan dengan $\mathrm{Cd}-\mathrm{Cu}$ selama 90 menit. Kemudian dipindahkan ke dalam tabung, direaksikan dan diinkubasi pada kondisi optimumnya. Kemudian diukur absorbansinya. Optimasi untuk waktu reduksi dilakukan dengan memilih salah satu reduktor yang memberikan hasil reduksi yang lebih baik dengan massa yang optimum. Sampel direduksi dengan rentang waktu 5-90 menit.

\section{Validasi}

Validasi metode dilakukan terhadap nitrit dan nitrat dalam air bebas ion, serum kontrol dan serum. Validasi terdiri atas penetapan linieritas, rentang, keseksamaan dan kecermatan menggunakan metode yang telah dioptimasi. Penetapan linieritas dan rentang dibuat dengan konsentrasi 10-100 $\mu \mathrm{M}$.

\section{Penentuan Kadar Total Nitrit} dengan Metode Baku Tinambah

Sebanyak $250 \mu \mathrm{L}$ larutan simulasi air bebas ion yang mengandung $80 \%(10 \mu \mathrm{M}$ nitrit dan $30 \mu \mathrm{M}$ nitrat), $100 \%$ (15 $\mu \mathrm{M}$ nitrit dan $35 \mu \mathrm{M}$ nitrat) dan $120 \%$ analit $(20 \mu \mathrm{M}$ nitrit dan $40 \mu \mathrm{M}$ nitrat) dimasukkan ke dalam tabung reaksi. Masing-masing level dibuat empat tabung, ke dalam setiap tabung ditambahkan $1 \mathrm{~mL}$ air bebas ion. Kemudian dipindahkan, dan direduksi dengan 1,5 granul $\mathrm{Zn}-\mathrm{Cu}$ selama 10 menit. $\mathrm{Ke}$ dalamnya kemudian ditambahkan baku tinambah dengan konsentrasi 10-60 $\mu \mathrm{M}$. Sampel selanjutnya direaksikan dan diinkubasi selama 30-40 menit. Kemudian diukur absorbansinya. Absorbansi yang diperoleh kemudian diekstrapolasi melewati sumbu y $=0$. Kadar sampel dapat ditentukan dan dihitung $\%$ perolehan kembalinya.

\section{Penentuan Kadar Total Nitrit dalam Serum Kontrol dengan Metode Baku Tinambah}

Sebanyak $250 \mu \mathrm{L}$ larutan simulasi serum kontrol yang mengandung $80 \%$ (10 $\mu \mathrm{M}$ nitrit dan $30 \mu \mathrm{M}$ nitrat), $100 \%$ (15 $\mu \mathrm{M}$ nitrit dan $35 \mu \mathrm{M}$ nitrat) dan $120 \%$ analit (20 $\mu \mathrm{M}$ nitrit dan $40 \mu \mathrm{M}$ nitrat) dimasukkan ke dalam tabung sentrifuga. Masing-masing level dibuat empat tabung. Selanjutnya diproteinisasi dengan $0,5 \mathrm{~mL} \mathrm{ZnSO}_{4}$ dan 0,5 $\mathrm{mLNaOH}$ dan disentrifugasi dengan kecepatan $5000 \mathrm{rpm}$ selama 10 menit. Kemudian direduksi dengan 1,5 granul $\mathrm{Zn}$ $\mathrm{Cu}$ selama 10 menit. Ke dalamnya kemudian 
ditambahkan baku tinambah dengan konsentrasi $10-60 \mu \mathrm{M}$. Sampel selanjutnya direaksikan dan diinkubasi selama 30-40 menit. Kemudian diukur absorbansinya. Absorbansi yang diperoleh kemudian diekstrapolasi melewati sumbu y $=0$. Kadar sampel dapat ditentukan dan dihitung \% perolehan kembalinya.

\section{HASIL}

Penentuan kadar NO di dalam matriks biologi dilakukan secara tidak langsung melalui pengukuran metabolit utamanya berupa nitrit dan nitrat. Nitrit bersifat kurang stabil dan di dalam darah akan cepat berubah menjadi nitrat. Pada penelitian ini, reaksi yang digunakan adalah reaksi Griess, yaitu untuk menentukan kadar nitrit, dengan demikian nitrat yang dihasilkan harus terlebih dahulu direduksi menjadi nitrit. Metode Griess didasarkan pada reaksi nitrit yang dihasilkan oleh autoksidasi NO dengan sulfanilamida menghasilkan garam diazonium, yang selanjutnya bereaksi dengan n-1-naphthylethylenediamine menjadi pewarna azo yang dapat diukur secara spektroskopi ultraviolet/visible (Schatzschneider, 2017).
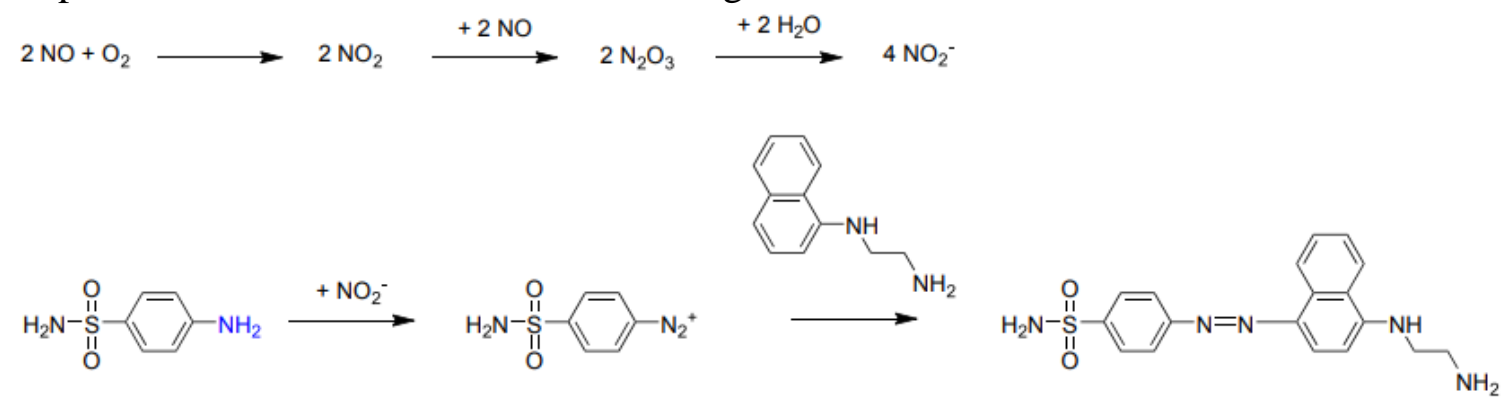

Gambar 1. Reaksi Diazotasi dan Kopling (Schatzschneider, 2017)

Hasil optimasi reduktor dapat dilihat pada tabel 1 di bawah berikut.

Tabel 1. Optimasi Massa Reduktor

\begin{tabular}{|c|c|c|c|c|c|c|}
\hline \multirow{2}{*}{$\begin{array}{l}\text { Massa } \\
\text { granul } \\
\text { (gram) }\end{array}$} & \multicolumn{3}{|c|}{$\begin{array}{l}\text { \% Perolehan Kembali dengan granul Cd } \\
\text { lapis } \mathrm{Cu}(\mathrm{n}=6)\end{array}$} & \multicolumn{3}{|c|}{$\begin{array}{l}\text { \% Perolehan Kembali dengan granul Zn lapis } \\
\qquad \mathrm{Cu}(\mathrm{n}=6)\end{array}$} \\
\hline & Rata-rata & SD & $\mathrm{KV}$ & Rata-rata & SD & $\mathrm{KV}$ \\
\hline 0,5 & 28,874 & 12,586 & 43,591 & 20,966 & 1,7835 & 8,507 \\
\hline 1 & 73,414 & 19,373 & 26,389 & 41,490 & 10,364 & 24,979 \\
\hline 1,5 & 102,966 & 12,828 & 12,459 & 93,793 & 2,883 & 3,074 \\
\hline
\end{tabular}

Keterangan: SD: standar deviasi; KV: koefisien variansi; Cd: kadmium; Zn: seng; Cu: tembaga

Validasi metode dilakukan pada beberapa parameter yaitu penentuan rentang dan linieritas, batas deteksi dan kuantitasi, keterulangan nitrit intra dan antar hari, keterulangan pengukuran nitrit intra dan antar hari, serta penentuan akurasi total nitrit. 


\section{Sari, dkk}

DOI : https://doi.org/10.24843/JFU.2021.v10.i01.p09

pISSN: 2301-7716; eISSN: 2622-4607

Jurnal Farmasi Udayana, Vol 10, No 1, Tahun 2021, 79 - 85

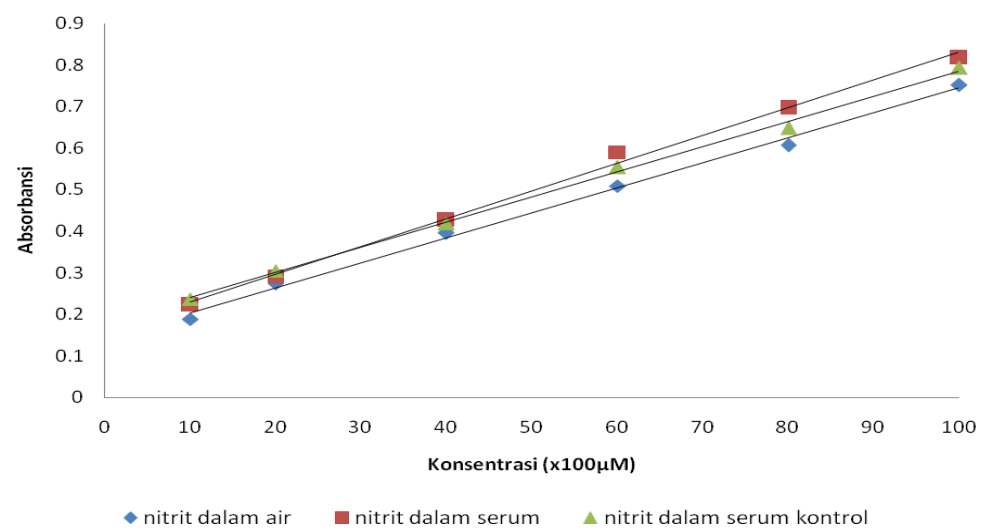

Gambar 2. Kurva Kalibrasi Nitrit

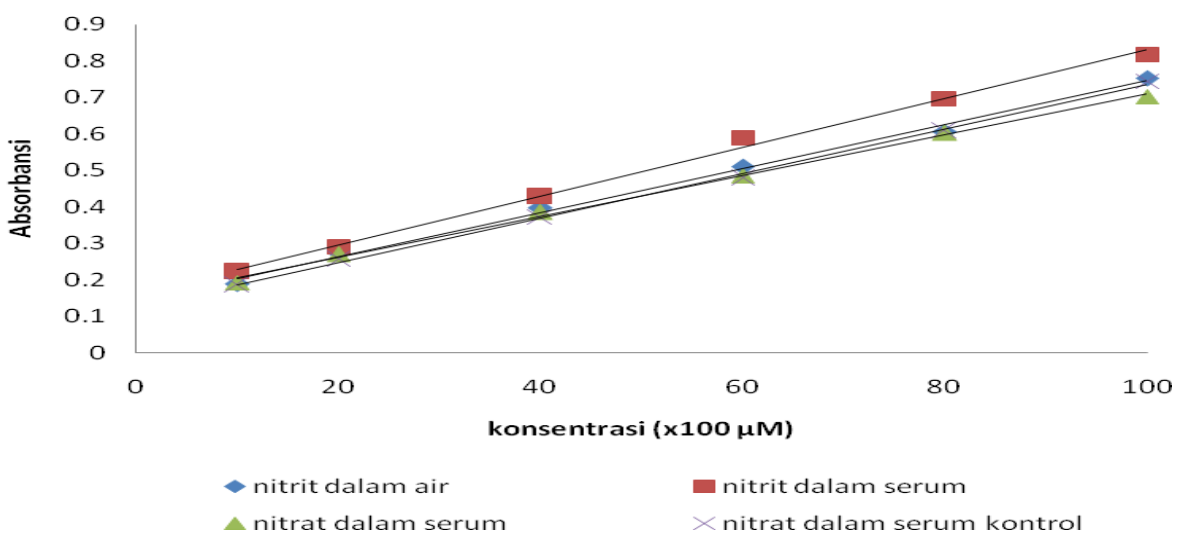

Gambar 3. Kurva Kalibrasi Nitrat

Tabel 2. Linieritas, Batas Deteksi dan Kuantitasi Nitrit

\begin{tabular}{lccccc}
\hline Parameter & $\begin{array}{c}\text { Air bebas } \\
\text { ion }\end{array}$ & Serum kontrol & Serum & $\begin{array}{c}\text { Nitrat dalam } \\
\text { serum }\end{array}$ & $\begin{array}{c}\text { Nitrat dalam } \\
\text { serum kontrol }\end{array}$ \\
\hline Persamaan & $\begin{array}{c}\mathrm{y}=0,601.10^{-2} \\
\mathrm{x}+0,143\end{array}$ & $\begin{array}{c}\mathrm{y}=0,578.10^{-2} \mathrm{x} \\
+0,193\end{array}$ & $\begin{array}{c}\mathrm{y}=0,669.10^{-2} \mathrm{x} \\
+0,161\end{array}$ & $\begin{array}{c}\mathrm{y}=0,558.10^{-2} \mathrm{x} \\
+0,151\end{array}$ & $\mathrm{y}=0,608.10^{-2} \mathrm{x}$ \\
$+0,126$
\end{tabular}

Keterangan: $\mathrm{LOD}=$ limit of detection; $\mathrm{LOQ}=$ limit of quantitation; $\mathrm{Vxo}=$ variansi; $\mu \mathrm{M}=$ mikro molar

Tabel 3. Keterulangan Nitrit Intra dan Antar Hari

\begin{tabular}{lrrrrrr}
\hline \multicolumn{1}{c}{ Pengulangan } & \multicolumn{3}{c}{ Intra hari } & \multicolumn{4}{c}{ Antar hari } \\
\cline { 2 - 7 } & $80 \%$ & $100 \%$ & $120 \%$ & $80 \%$ & $100 \%$ & $120 \%$ \\
\hline Rata-rata & 0,247 & 0,314 & 0,360 & 0,246 & 0,313 & 0,358 \\
\hline Standar deviasi & 0,004 & 0,004 & 0,007 & 0,001 & 0,004 & 0,006 \\
\hline Koefisien variansi & 1,683 & 1,388 & 1,953 & 0,406 & 1,332 & 1,536 \\
\hline
\end{tabular}


Sari, dkk

DOI : https://doi.org/10.24843/JFU.2021.v10.i01.p09

pISSN: 2301-7716; eISSN: 2622-4607

Jurnal Farmasi Udayana, Vol 10, No 1, Tahun 2021, 79 - 85

Tabel 4. Akurasi Total Nitrit

\begin{tabular}{ccccccc}
\hline & \multicolumn{2}{c}{ Air bebas ion } & \multicolumn{3}{c}{ Serum kontrol } \\
\hline Kadar & $\begin{array}{c}\text { Rata-Rata } \\
(\mathbf{\%}) \\
(\mathbf{n = 3})\end{array}$ & $\begin{array}{c}\text { Standar } \\
\text { deviasi }\end{array}$ & $\begin{array}{c}\text { Koefisien } \\
\text { variansi } \\
(\boldsymbol{\%})\end{array}$ & $\begin{array}{c}\text { Rata-Rata } \\
(\boldsymbol{\%}) \\
(\mathbf{n}=\mathbf{3})\end{array}$ & $\begin{array}{c}\text { Standar } \\
\text { deviasi }\end{array}$ & $\begin{array}{c}\text { Koefisien } \\
\text { variansi } \\
(\boldsymbol{\%})\end{array}$ \\
\hline $\mathbf{8 0 \%}(\mathbf{4 0} \boldsymbol{\mu M})$ & 110,28 & 3,99 & 3,62 & 97,10 & 1,10 & 1,13 \\
\hline $\mathbf{1 0 0 \%}(\mathbf{5 0} \boldsymbol{\mu M})$ & 113,11 & 1,37 & 1,22 & 91,27 & 0,87 & 0,95 \\
\hline $\mathbf{1 2 0 \%}(\mathbf{6 0} \boldsymbol{\mu M})$ & 106,41 & 2,18 & 2,05 & 106,45 & 2,71 & 2,55 \\
\hline
\end{tabular}

\section{PEMBAHASAN}

Nitrit terlebih dahulu direaksikan dengan pereaksi diazotasi, yang dalam keadaan asam akan menghasilkan garam diazonium. Intermediet ini kemudian direaksikan kembali dengan pereaksi kopling berupa nnaftiletilendiamin untuk membentuk senyawa azo yang berwarna keunguan. Dari hasil pengukuran didapatkan bahwa panjang gelombang maksimum larutan simulasi nitrit adalah $540 \mathrm{~nm}$. Adapun reaksi yang terjadi dapat dilihat pada Gambar 1 di bawah berikut.

Metode standar untuk reduksi nitrat menjadi nitrit adalah dengan menggunakan enzim nitrat reduktase dan kadmium lapis tembaga. Pada metode ini reduksi dilakukan dengan 2,5-3 gram granul kadmium dengan waktu reduksi 75-90 menit. Batas deteksi dari metode ini adalah 2-250 $\mu \mathrm{M}$ dengan koefisien variansi 4,7-9\%. Pada metode ini reduksi nitrat dilakukan dengan menggunakan logam seng yang dilapisi tembaga dan dibandingkan dengan kadmium lapis tembaga. Reduksi nitrat menjadi nitrit dengan logam sangat tergantung pada massa dan luas permukaan logam yang digunakan.

Logam seng bersifat lebih reaktif dari kadmium untuk itu pada metode ini dicoba untuk menggunakan logam seng dengan massa yang lebih sedikit (0,5-1,5 g) dengan ukuran granul yang lebih besar $(0,2-0,4 \mathrm{~g})$, yang kemudian dibandingan dengan metode kadmium lapis tembaga. Tabel 1 menunjukkan bahwa reduksi nitrat dengan menggunakan seng lapis tembaga pada massa 1,5 gram memiliki keterulangan yang lebih baik dan $\%$ perolehan kembali yaitu > $90 \%$.

Penentuan linieritas, rentang, batas deteksi dan batas kuantitasi nitrit dan nitrat dilakukan menggunakan larutan simulasi air bebas ion, dalam serum kontrol dan dalam serum dengan rentang konsentrasi 10-100 $\mu \mathrm{M}$. Pada rentang konsentrasi tersebut, nitrit dan nitrat memiliki linieritas yang baik, di mana pada ketiga larutan masing-masing persamaan regresi memberikan koefisien korelasi yang lebih besar dari 0,995.

Pada gambar 2 di atas menunjukkan bahwa dalam ketiga larutan, nitrit memiliki profil kurva kalibrasi yang hampir sama. Besar koefisien variansi regresi nitrit yang diperoleh sebesar 4,15\%; 3,82\% dan 4,97\% dalam air bebas ion, serum kontrol dan dalam serum. Sementara itu untuk nitrat Besar koefisien variansi regresi yang diperoleh sebesar $3,75 \%$ dan 3,15 dalam serum dan serum kontrol. Nilai ini lebih rendah dari yang dipersyaratkan yaitu $\leq 5 \%$. Adapun batas deteksi dan kuantitasi metode ini lebih rendah dari kadar nitrit total pasien normal.

Keterulangan metode dilakukan pada tiga level dengan tiga kali pengulangan yang masing-masing dilakukan intra dan antar hari. Hasil yang diperoleh menunjukkan bahwa metode yang digunakan memiliki keterulangan yang baik, yang mana pada 
DOI : https://doi.org/10.24843/JFU.2021.v10.i01.p09

pISSN: 2301-7716; eISSN: 2622-4607

Jurnal Farmasi Udayana, Vol 10, No 1, Tahun 2021, 79 - 85

masing-masing pengujian besarnya nilai koefisien variansi adalah $\leq 15 \%$.

Penentuan kecermatan (akurasi) dilakukan dalam air bebas ion dan dalam serum kontrol dengan metode baku tinambah. Penentuan kecermatan ini dilakukan pada 3 level masing-masing dengan tiga kali pengulangan.

Penentuan akurasi dilakukan pada dua jenis sampel simulasi, yaitu pada air bebas ion dan pada serum control. Masing-masing sampel simulasi dibuat dalam tiga level konsentrasi yaitu $80 \%, 100 \%$ dan $120 \%$. Hasil yang diperoleh adalah metode yang dikembangkan memenuhi ketentuan kecermatan yaitu pada rentang $85-115 \%$.

\section{KESIMPULAN}

Massa reduktor granul seng lapis tembaga yang optimal adalah 1,5 g dengan waktu reduksi 10 menit, koefisien variansi $\leq 5 \%$. Koefisien korelasi $>0,995$ dengan $\mathrm{Vx} 0 \leq$ $5 \%$, keseksamaan $\leq 15 \%$, dan kecermatan $85-115 \%$.

\section{DAFTAR PUSTAKA}

Malerba, M., Radaeli, A., Olivini, A., Damiani, G., Ragnoli, B., Montuschi, P., Ricciardolo, F.L.M. (2014). Exhaled Nitric Oxide as a Biomarker in COPD and Related Comorbidities. Hindawi Publishing Corporation BioMed Research International,
Volume

2014.

http://dx.doi.org/10.1155/2014/271918.

Nagy, G., Koncz, A., Telarico, T., Fernandez, D., Ersek, B., Buzas E., Perl, A. (2010). Central Role of Nitric Oxide in The Pathogenesis of Rheumatoid Arthritis and Systemic Lupus Erythematosus. Arthritis Research \& Therapy, 12:210.

Oates, J.C. (2010). The Biology Of Reactive Intermediates In Systemic Lupus Erythematosus. National Institute of Health, Autoimmunity, 43(1): 56-63. doi:10.3109/08916930903374683.

Schatzschneider, U. (2017). Inorganic and Organometallic Transition Metal Complexes with Biological Molecules and Living Cells. Elsevier Inc. http://dx.doi.org/10.1016/B978-0-12803814-7.00006-X.

Silver, J.H. 2011, Nitrite and Nitric Oxide as Potential Diagnostic Markers in Acute Vascular Diseases. Journal of Neurology \& Neurophysiology. DOI: 10.4172/2155-9562.S1-005

Tatsch, E., Bochi, G.V. , da Silva Pereira, R., Kober, H., Agertt, V.A., de Campos, M.M.A., Gomes, P., Duarte, M.M.M.F., Moresco, R.N., 2011, A Simple and Inexpensive Automated Technique for Measurement of Serum Nitrite/Nitrate, Clinical Biochemistry, 44 , 